\title{
RANCANG BANGUN ELEKTROMIOGRAFI PERMUKAAN PORTABEL
}

\section{DESIGN AND DEVELOPMENT OF PORTABLE SURFACE ELECTROMYOGRAPHY}

\author{
Aulia el Hakim ${ }^{1}$, Hendrik Kusbandono ${ }^{2}$, Fata Izzan Hafidz Jihaadi ${ }^{3}$, Riska Widiyaningsih Fata ${ }^{4}$ \\ 1,2,3,4 Jurusan Teknik, Politeknik Negeri Madiun, Madiun, Indonesia \\ 1aim@pnm.ac.id, ${ }^{2} \underline{\text { h3ndrik57@pnm.ac.id, }}, \underline{{ }^{3} \text { fata.0606@ gmail.com, }}, \underline{{ }^{4} \text { riskawidiya@ gmail.com }}$
}

\begin{abstract}
Abstrak
Kelemahan otot merupakan kondisi ketika salah satu sisi tubuh mengalami kelemahan dan sulit untuk digerakkan. Kelemahan otot umumnya dapat diketahui dengan menggunakan peralatan Electromyography (EMG). Akan tetapi Electromyography hanya dapat digunakan oleh tenaga medis dan mengeluarkan biaya cukup mahal. Maka dari itu pembuatan surface Electromyography secara portabel ini ditujukan untuk membantu bagi pengguna dalam mengetahui kondisi kekuatan otot secara mandiri tanpa harus pergi ke instansi kesehatan. Sinyal otot dapat dibaca dengan adanya elektroda permukaan yang terhubung dengan rangkaian Differential Amplifier, kemudian sinyal diolah dengan rangkaian Fiter LPF, HPF dan Notch Filter untuk mengurangi noise, dan rangkaian adder untuk menaikkan sinyal agar dapat dibaca ADC yang terhubung dengan Raspberry pi dan dapat dikoneksikan melalui bluetooth. Pengujian keseluruhan Surface Electromyography mampu membaca dan menampilkan sinyal pada Raspberry pi dan dapat mengetahui jenis gerakan dengan menggunakan metode FFT dan MPF. Jenis gerakan fleksi mempunyai nilai MPF kurang dari $180 \mathrm{~Hz}$ dan gerakan ekstensi mempunyai nilai MPF lebih dari $180 \mathrm{~Hz}$
\end{abstract}

\section{Kata kunci: Kelemahan otot, Surface Electromyography, Rangkaian Filter, FFT, MPF}

\begin{abstract}
Muscle weakness is a condition when one side of the body is weak and difficult to move. Muscle weakness can generally be identified using Electromyography (EMG) equipment. However, Electromyography can only be used by health care workers and is quite expensive. Therefore, the manufacture of surface Electromyography in a portable manner is intended to assist users in knowing the condition of muscle strength independently without having to go to a health institution. The muscle signal can be read with a surface electrode connected to the Differential Amplifier circuit, then the signal is processed with a series of filter Circuit LPF, HPF, and Notch Filter to reduce noise, and an adder circuit to increase the signal so that it can be read as ADC which is connected to Raspberry pi and can be connected via Bluetooth. Overall testing Surface Electromyography is able to read and display signals on the Raspberry pi and can determine the type of movement using the FFT and MPF methods. The type of flexion motion has an MPF value of less than $180 \mathrm{~Hz}$ and the extension movement has an MPF value of more than $180 \mathrm{~Hz}$.
\end{abstract}

Keywords: Muscle weakness, Surface Electromyography, Filter Circuit, FFT, MPF

\section{PENDAHULUAN}

Sinyal biomedis merupakan sinyal yang dapat diukur dan dianalisis untuk mengetahui informasi mengenai struktur dan fungsi dari sistem biologis sebuah organ tubuh. Sinyal biomedis yang didapatkan dari dalam tubuh manusia ada beberapa macam, salah satunya yaitu sinyal 
Electromyography (EMG) [1]. Electromyography (EMG) merupakan teknik untuk mengevaluasi aktivitas listrik yang dihasilkan oleh otot selama kontraksi atau relaksasi[2].

Pada umumnya EMG digunakan untuk menunjukkan adanya gangguan pada kekuatan otot yang terdapat pada penyandang cacat, baik karena pasca-cedera atau penyebab lain seperti Pasca Stroke. Sinyal EMG dianggap mencakup informasi kekuatan aktivitas otot dan kelelahan otot[3]. Pada dunia olahraga atau kebugaran, sinyal EMG digunakan untuk menganalisis kebugaran atlet melalui informasi yang direkam dari sinyal otot atlet [4]. Ada dua jenis EMG yaitu EMG Intramuskular dan EMG permukaan. EMG intramuskular menggunakan dua jarum elektroda halus yang dimasukkan melalui kulit ke dalam jaringan otot. Dalam praktik klinis prosedur ini memiliki kelemahan dalam aplikasi seperti neurorehabilitasi,pemeriksaan anak-anak, pelatihan atlet, serta dalam banyak kasus lain di mana kondisi akuisisi tidak dapat dikontrol secara ketat atau di mana sifat invasif dari EMG yang dimasukkan melalui kulit mencegah penggunaan sehari-hari[5]. Sedangkan untuk tipe EMG permukaan, bekerja dengan menempatkan dua elektroda pada permukaan kulit dengan penempatan yang berbeda pada area otot [6][7]. Dalam aplikasi EMG permukaan, perubahan kondisi dan indeks aktivitas tidak hanya berisi informasi tentang sumber yang diinginkan, tetapi juga terdapat noise [8].

Berdasarkan hal tersebut, dalam penelitian ini digunakan sensor elektroda jenis permukaan dan pembuatan rangkaian instrumentasi Electromyography diharapkan dapat menghasilkan sinyal yang dapat diproses untuk mengetahui kondisi kekuatan otot berupa sinyal amplitudo terutama pada pasien pasca stroke atau cidera otot dan dapat digunakan untuk mengidentifikasi jenis gerakan pada otot tersebut. Alat ini juga didesain secara portabel sehingga diharapkan dapat lebih mudah dalam penggunaanya.

\section{MATERIAL DAN METODOLOGI}

Pada Bab ini Akan menjelaskan tentang diagram sistem, serta rangkaian instrumentasi yang sudah dibuat.

\subsection{Diagram Sistem}

Dalam metode penelitian terdapat diagram sistem kerja yang dibuat untuk perangkat dari "Portable Surface Electromyography"

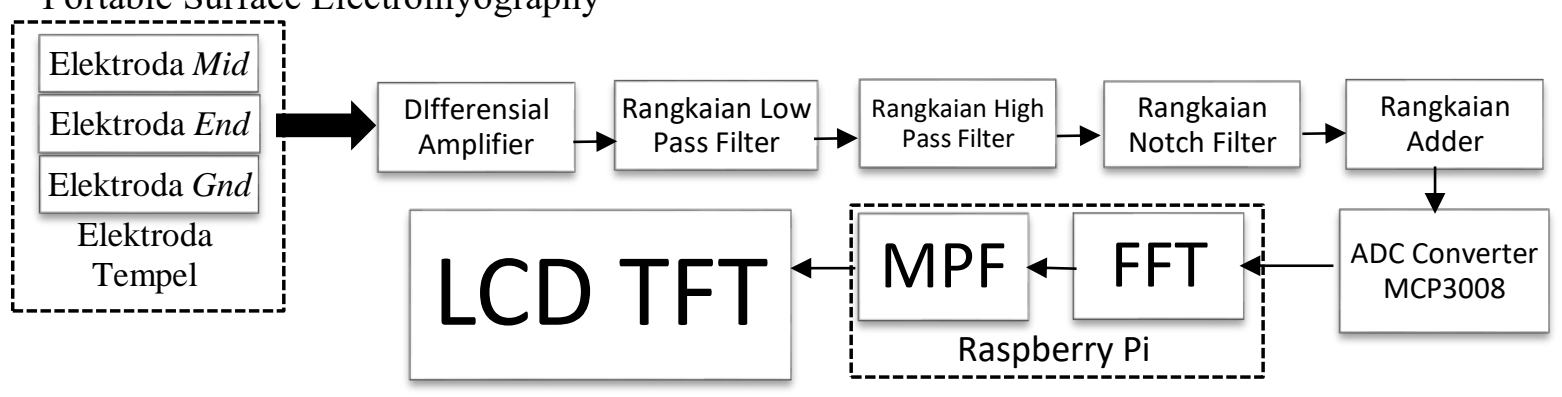

Gambar 1. Diagram sistem.

Berdasarkan diagram sistem pada gambar 1, dapat diketahui bahwa elektroda tempel digunakan untuk mendapatkan sinyal dari otot lengan yang diperiksa. Sinyal yang didapatkan dari elektroda tempel kemudian diolah menggunakan beberapa rangkaian instrumentasi Electromyography. Rangkaian differential amplifier digunakan sebagai pembanding antara elektroda bagian mid dan elektroda bagian end. Serta digunakan sebagai penguat sinyal masukan dari elektroda, hal ini dikarenakan keluaran dari elektroda tidak lebih dari $10 \mathrm{mV}$ sehingga diperlukan rangkaian penguat[9]. Rangkaian Low Pass Filter (LPF), rangkaian High Pass Filter (HPF) dan rangkaian Notch Filter digunakan untuk mendapatkan frekuensi sinyal otot yang diinginkan, karena sinyal yang didapatkan dari elektroda masih tercampur dengan noise. Selanjutnya digunakan rangkaian adder 
untuk menggeser sinyal Electromyography agar amplitudo keseluruhan sinyal Electromyography berada pada tegangan positif. Sehingga ADC converter dapat membaca sinyal Electromyography yang dihasilkan. Sinyal yang sudah dibaca oleh ADC converter MCP3008 kemudian diolah dan dilakukan denoising sinyal dengan menggunakan metode Fast Fourier Transform (FFT) [10] dan dihitung nilai Mean Power Frequency (MPF) dari sinyal yang didapat. Hasil dari sinyal dan MPF ditampilkan pada LCD TFT.

\subsection{Perancangan rangkaian}

Pada bagian perancangan rangkaian akan dijelaskan skematik rangkaian yang digunakan pada perangkat surface Electromyography. Komponen yang digunakan adalah resistor dengan toleransi 1\%, kapasitor, TL072, elektroda permukaan, raspberry pi 3, MCP3008, LCD TFT, baterai LiPo 2 Cell 7.4Volt. Adapun beberapa perancangan rangkaian skematik pada perangakat surface Electromyography sebagai berikut:

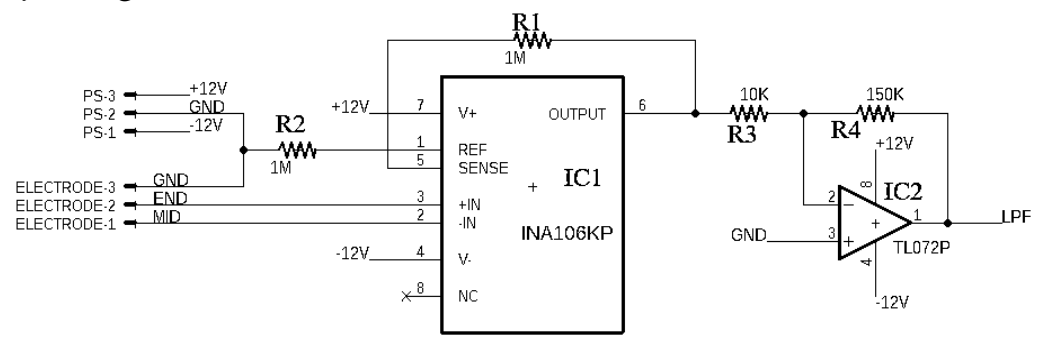

Gambar 2. Rangkaian differential amplifier.

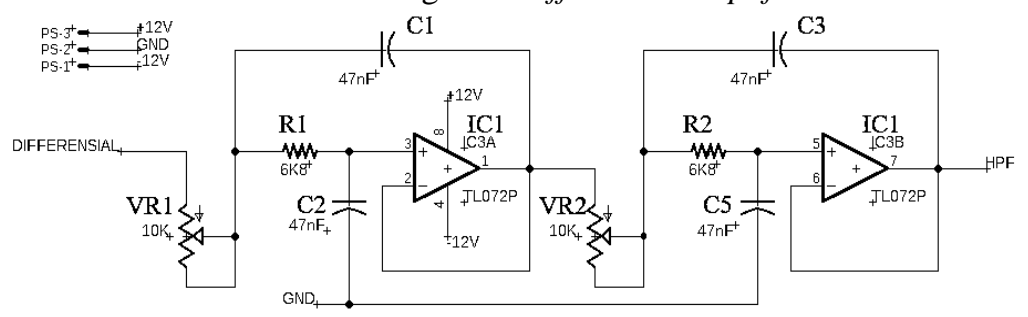

Gambar 3. Rangkaian Low Pass Filter orde 4.

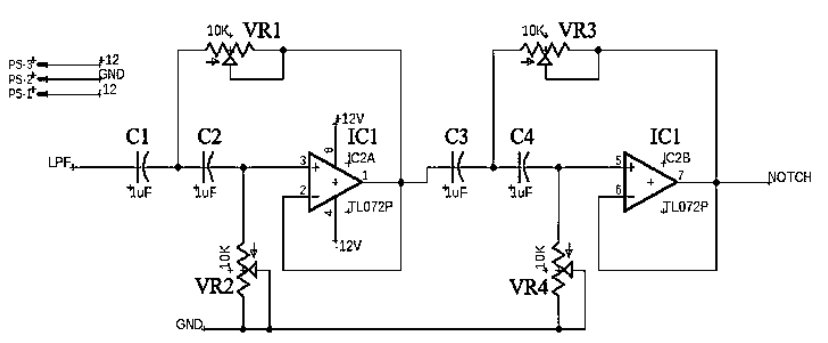

(a)

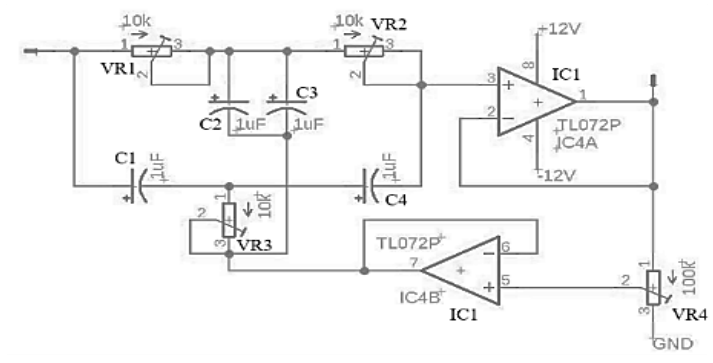

(b)

Gambar 4. (a) Rangkaian High Pass Filter orde 4. (b) Rangkaian Notch Filter atau Twin-T.

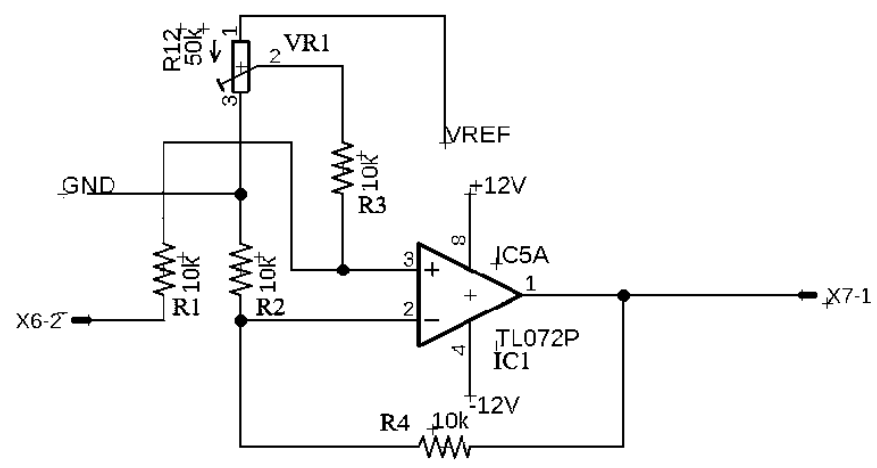

Gambar 5. Rangkaian Adder. 


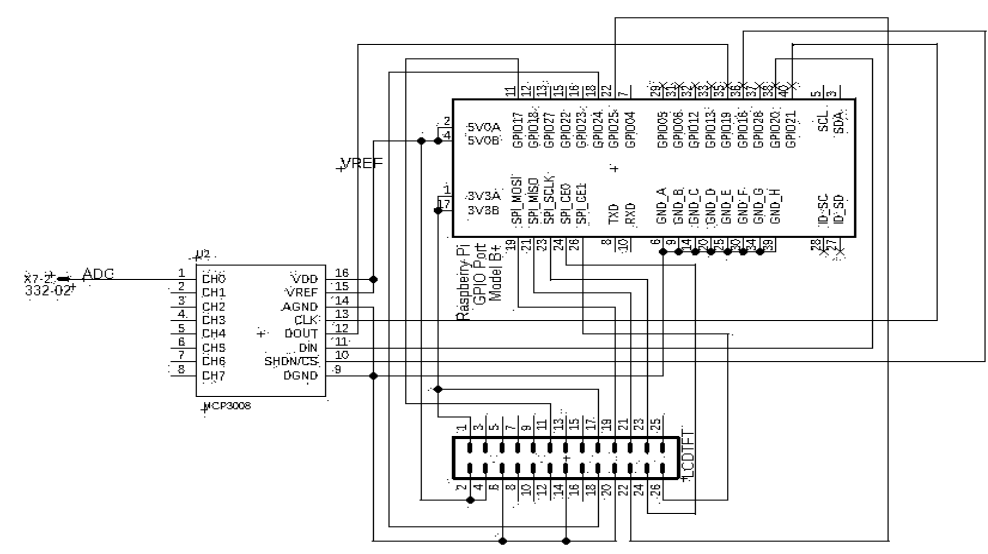

Gambar 6. Rangkaian MCP3008, Raspberry Pi, dan LCD TFT.

Gambar 2 menjelaskan tentang rangkaian differential amplifier dengan rangkaian penguat pembalik. Gambar 3 menjelaskan rangkaian Low Pass Filter orde 4 dengan frekuensi Cut-Off 500Hz. Gambar 4(a) menjelaskan rangkaian High Pass Filter orde 4 dengan frekuensi Cut-Off 20Hz. Gambar 4(b) menjelaskan rangkaian Notch Filter atau Twin-T dengan frekuensi Cut-Off Center $50 \mathrm{~Hz}$. Gambar 5 Rangkaian Adder atau Summing Amplifier. Gambar 6 menjelaskan rangkaian antara Raspberry pi dengan ADC converter MCP3008 dan LCD TFT.

\section{PEMBAHASAN}

Perlu dilakukan beberapa pengujian terhadap sistem yang sudah dibuat. Hal ini bertujuan untuk mengetahui apakah sistem dapat bekerja dengan baik atau tidak.

\subsection{Differential amplifier}

Pada penelitian ini menggunakan IC INA106 yang merupakan IC dari rangkaian differential amplifier. Berikut adalah persamaan dari penguatan rangkaian differential amplifier dan penguat inverting:

$$
\text { Vout }=-\left(-V 1\left(\frac{R 3}{R 1}\right)+V 2\left(\frac{R 4}{R 2+R 4}\right)\left(\frac{R 1+R 3}{R 1}\right)\right)\left(\frac{R 6}{R 5}\right)
$$

Dari persamaan 1 maka dapat dihitung nilai Vout. Pada rangkaian differential amplifier mempunyai penguatan sebesar 110x dan pada rangkaian penguat inverting mempunyai penguatan 15x sehingga output amplitudo yang dihasilkan sekitar 1V. Sinyal yang dihasilkan dari rangkaian differential amplifier mempunyai amplitudo yang kecil sehingga dikuatkan dengan rangkaian penguat inverting. Penguatan total yang dihasilkan dari rangkaian differential amplifier dan penguat inverting sebesar 1620 kali.

\subsection{Rangkaian Low Pass Filter}

Pada penelitian ini menggunakan rangkaian Low Pass Filter orde 4. Frekuensi cut-off yang digunakan pada rangkaian ini adalah $500 \mathrm{~Hz}$. Frequensi cut-off dapat dihitung dengan persamaan sebagai berikut:

$$
F C=\frac{1}{2 \pi \sqrt{C 1 \times C 2 \times R 1 \times R 2}}
$$

Dari persamaan 2 maka dapat dihitung frekuensi cut-off pada rangkaian Low Pass Filter atau dapat digunakan untuk mencari nilai dari komponen. Keluaran dari rangkaian Low Pass Filter dapat dihitung dengan menggunakan persamaan berikut: 


$$
\begin{aligned}
& A C L=\frac{1}{\sqrt{1+\left(\frac{F c}{F i n}\right)^{4}}} \\
& V p p=A C L^{2} \times \operatorname{Vin}
\end{aligned}
$$

Berdasarkan perhitungan dari persamaan 4 dan pengujian rangkaian dengan oscilloscope maka didapatkan perbandingan respon Vpp dari rangkaian Low Pass Filter. Vin yang digunakan untuk pengujian rangkaian sebesar $2.1 \mathrm{~V}$.

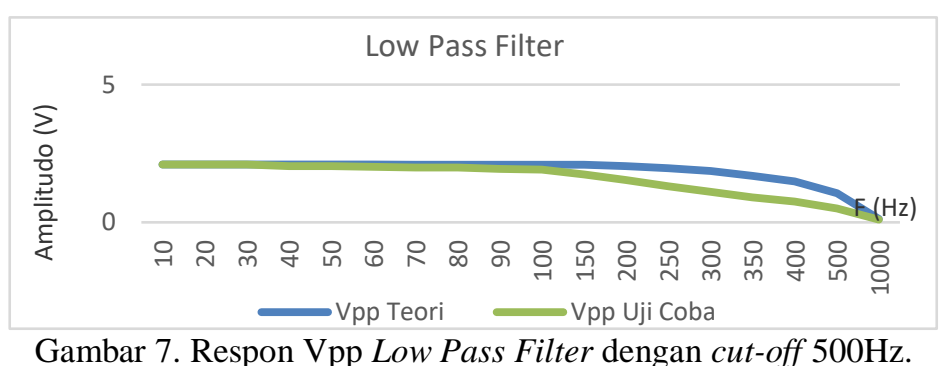

Berdasarkan pengujian pada gambar 7 diketahui bahwa pada frekuensi tertentu, respon Vpp dari rangkaian kurang akurat. Hal ini dikarenakan adanya perbedaan nilai komponen pada teori dengan komponen pada rangkaian.

\subsection{Rangkaian High Pass Filter}

Pada penelitian ini menggunakan rangkaian High Pass Filter orde 4. Frekuensi cut-off yang digunakan pada rangkaian ini adalah $20 \mathrm{~Hz}$. Frequensi cut-off dapat dihitung dengan persamaan sebagai berikut:

$$
F C=\frac{1}{2 \pi \sqrt{R 1 \times R 2 \times C 1 \times C 2}}
$$

Dari persamaan 5 maka dapat dihitung frekuensi cut-off pada rangkaian High Pass Filter atau dapat digunakan untuk mencari nilai dari komponen. Keluaran dari rangkaian High Pass Filter dapat dihitung dengan menggunakan persamaan berikut:

$$
A C L=\frac{1 \times\left(\frac{F i n}{F c}\right)}{\sqrt{1+\left(\frac{F i n}{F c}\right)^{2}}}
$$

Berdasarkan perhitungan dari persamaan 4 dengan perhitungan ACL menggunakan persamaan 6 dan pengujian rangkaian dengan oscilloscope maka didapatkan perbandingan respon Vpp dari rangkaian High Pass Filter. Vin yang digunakan pada saat pengujian rangkaian sebesar 2.02V

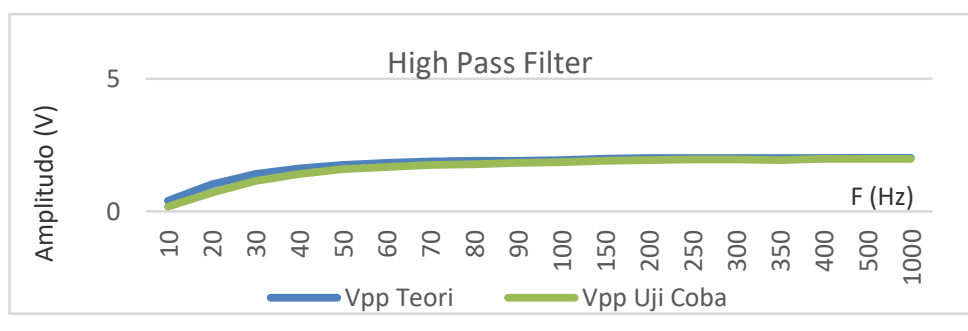

Gambar 8. Respon Vpp High Pass Filter dengan cut-off 20Hz.

Berdasarkan pengujian rangkaian pada gambar 8 diketahui bahwa pengujian Vpp pada rangkaian dengan perhitungan secara teori mempunyai perbedaan yang linier. Nilai komponen yang mempunyai toleransi menyebabkan adanya eror pada respon Vpp tiap frekuensinya. 


\subsection{Rangkaian Notch Filter}

Pada penelitian ini menggunakan rangkaian Notch Filter atau rangkaian Twin-T. Frekuensi cut-off center dari rangkaian ini adalah 50Hz. Frekuensi cut-off center dapat dihitung menggunakan persamaan sebagai berikut:

$$
F C=\frac{1}{4 \pi R C}
$$

Dari persamaan 7 maka dapat dihitung cut-off pada rangkaian notch filter. Berikut ini merupakan grafik respon Vpp dari rangkaian notch filter.

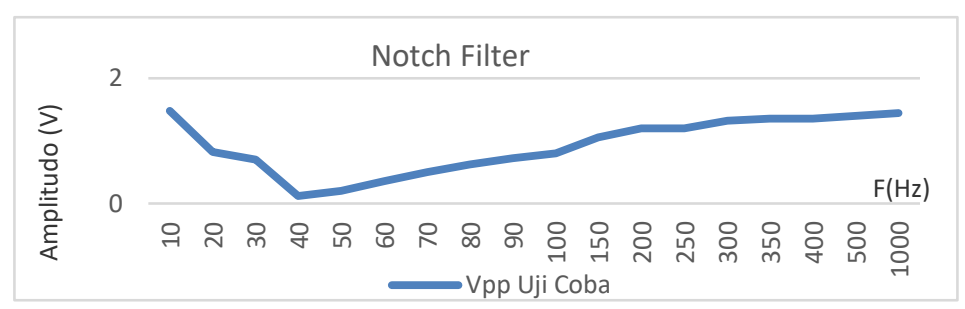

Gambar 9. Respon Vpp rangkaian notch filter.

Rangkaian Notch Filter mampu meredam frekuensi dengan titik terendah pada frekuensi $40 \mathrm{~Hz}$. Dari gambar 9. Rangkaian Notch filter sudah sesuai dengan prinsip kerja dari rangkaian Notch filter.

\subsection{Rangkaian Adder}

Pada penelitian ini rangkaian adder digunakan untuk menaikkan amplitudo yaitu dengan cara menambahkan sinyal Electromyography dengan tegangan DC yang sudah diatur. Keluaran dari rangkaian adder dapat dihitung secara teori dengan menggunakan persamaan berikut:

$$
\text { Vout }=\left(\frac{R f}{R i}+1\right) \times \text { Rtotal } \times\left(\frac{V 1}{R 1}+\frac{V 2}{R 2}\right)
$$

Hasil dari pengujian dari rangkaian dan perhitungan dengan menggunakan persamaan 8 dapat dilihat pada tabel 1 .

\begin{tabular}{llllll}
\multicolumn{8}{c}{ Tabel 1. Hasil pengujian rangkaian adder. } \\
\hline V1 & V2 & Vout & Vout & Error & $\%$ \\
$(\mathrm{~V})$ & $(\mathrm{V})$ & Uji $(\mathrm{V})$ & Teori $(\mathrm{V})$ & $(\mathrm{V})$ & Error \\
\hline 1.00 & 0.00 & 0.98 & 1.00 & 0.018 & $1.75 \%$ \\
1.00 & 1.00 & 2.00 & 2.00 & 0.000 & $0.00 \%$ \\
1.00 & 2.00 & 3.10 & 3.00 & 0.103 & $3.44 \%$ \\
1.00 & 3.00 & 3.85 & 4.00 & 0.151 & $3.77 \%$ \\
1.00 & 4.00 & 4.93 & 5.00 & 0.074 & $1.48 \%$ \\
\hline \multicolumn{7}{l}{ Rata - Rata Error } & & 0.069 & $2.09 \%$ \\
\hline
\end{tabular}

Dilihat dari hasil pengujian pada tabel 1 mempunyai persentase error yang kecil sehingga ketika input berupa sinyal sinus, keluaran dari rangkaian adder tidak merubah bentuk sinyal.

\subsection{ADC converter}

Pada pengujian ini dilakukan untuk mengetahui banyak data yang diambil oleh ADC converter dalam 1 detik dan selama 2 detik. Hasil pengujian dapat dilihat pada tabel 2. Dari hasil pengujian tersebut didapatkan data sampel yang dapat diambil oleh ADC converter yaitu memiliki banyak data yang berbeda - beda. Sehingga dapat mempengaruhi bentuk sinyal emg. 
Tabel 2. Hasil pengujian banyak data oleh ADC converter.

\begin{tabular}{|c|c|c|c|}
\hline \multicolumn{2}{|c|}{$\begin{array}{c}\text { Banyak } \\
\text { sampel data }\end{array}$} & \multirow{2}{*}{\multicolumn{2}{|c|}{ Hasil sinyal pada LCD TFT }} \\
\hline $\begin{array}{l}1 \\
\text { detik }\end{array}$ & $\begin{array}{l}2 \\
\text { detik }\end{array}$ & & \\
\hline 2026 & 4169 & 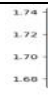 & 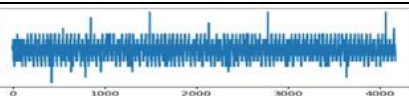 \\
\hline 2029 & 4140 & 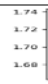 & 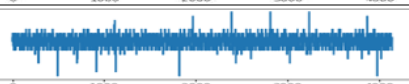 \\
\hline 1046 & 2096 & 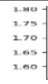 & 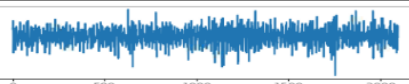 \\
\hline 2048 & 4162 & $\begin{array}{l}2.75 \\
2.70 \\
2.05 \\
2.00\end{array}$ & 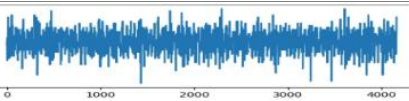 \\
\hline
\end{tabular}

\subsection{FFT dan MPF}

Pada pengujian ini menggunakan program yang dapat menghasilkan sinyal sinus untuk uji coba program FFT dan MPF dapat bekerja atau tidak. Secara sederhana dapat dikatakan bahwa DFT merupakan metode transformasi matematis sinyal waktu diskrit, sementara FFT adalah algoritma yang digunakan untuk melakukan transformasi tersebut. Secara matematis, DFT dapat dirumuskan sebagai berikut :

$$
X[k]=\sum_{n=0}^{N-1} x[n] . W_{N}^{n k} ; \mathrm{k}=0,1,2, \ldots, \mathrm{N}-1
$$

Dimana $W_{N}^{n k}$ disebut sebagai twiddle factor, memiliki nilai $e^{-\frac{j 2 \pi n k}{N}}$. FFT dipergunakan untuk mengurangi kompleksitas transformasi yang dilakukan dengan DFT. Sebagai perbandingan, bila kita menggunakan DFT, maka kompleksitas transformasi kita adalah sebesar O(N2), sementara dengan menggunakan FFT, selain waktu transformasi yang lebih cepat, kompleksitas transformasi pun menurun, menjadi $\mathrm{O}(\mathrm{N} \log (\mathrm{N}))$. Selain itu, terdapat persamaan yang digunakan untuk mencari rata - rata yang disebut Mean Power Frequency(MPF) yaitu sebagai berikut:

$$
M P F=\frac{\sum_{j=1}^{N} f_{j} P_{j}}{\sum_{j=1}^{N} P_{j}}
$$

Dimana $\mathrm{f}_{\mathrm{j}}$ merupakan nilai frekuensi dari spektrum daya EMG pada frekuensi bin $\mathrm{j}, \mathrm{P} \mathrm{j}$ adalah spektrum daya EMG pada frekuensi bin $\mathrm{j}$, dan $\mathrm{N}$ adalah panjang dari frekuensi bin. Dalam analisis sinyals EMG, $\mathrm{N}$ biasanya didefinisikan sebagai kekuatan berikutnya dari panjang data EMG dalam domain waktu. Berikut ini merupakan pengujian dari program FFT dan MPF yaitu sebagai berikut:

Tabel 3. Hasil pengujian FFT dan MPF.

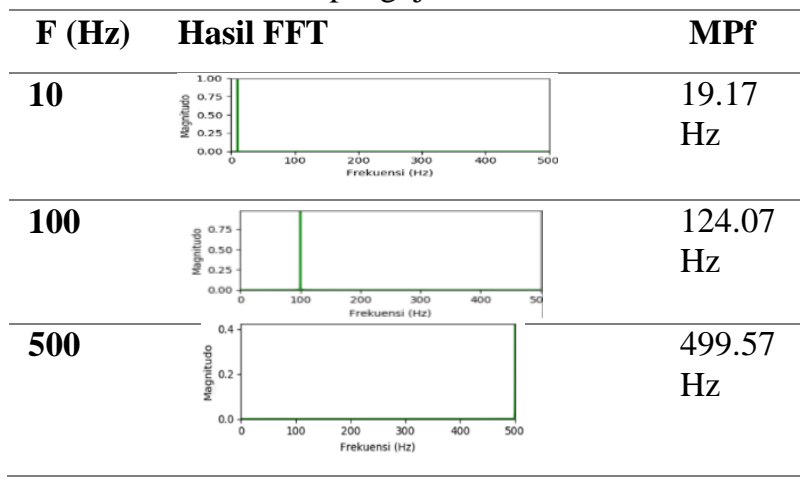




\subsection{Pengujian Keseluruhan}

Setelah melakukan pengujian terhadap masing - masing bagian dari sistem , maka selanjutnya dilakukan pengujian sistem kerja secara keseluruhan dan memastikan apakah alat tersebut dapat bekerja sesuai dengan perencanaan. Dalam pengujiannya apabila terdapat error maka akan dilakukan pengecekan ulang pada rangkaian atau program yang digunakan pada perangkat Portable Surface Electromyography. Gambar 10 (a) merupakan desain dari box kendali dan monitoring perangkat Portable sEMG.

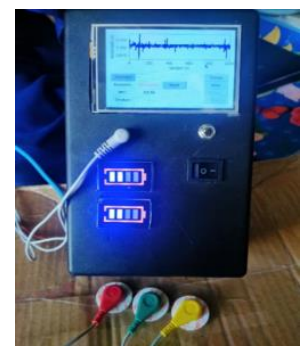

(a)

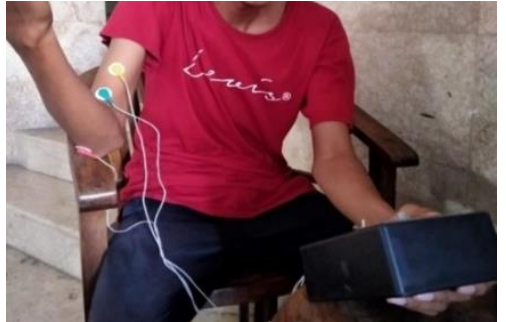

(b)

Gambar 10 (a). Perangkat surface Electromyography. (b) Pengujian keseluruhan alat.

Perangkat ini digunakan untuk mendeteksi sinyal pada otot bisep. Sehingga pengujian dilakukan dengan menempatkan elektroda tempel pada lengan otot bisep seperti pada gambar 10 (b). Elektroda warna merah ditempatkan pada bagian lengan yang sedikit otot yang berfungsi sebagai ground. Elektroda warna hijau dan kuning ditempatkan pada bagian ujung dan tengah dari otot bisep. Pengujian dilakukan dengan cara menggerakkan lengan secara fleksi atau dengan kondisi lengan menekuk dengan kekuatan penuh dan menggerakkan lengan secara ekstensi atau dengan kondisi lengan lurus dan lemas. Berikut ini merupakan hasil dari pengujian sistem dari perangkat Portable surface electromyography.

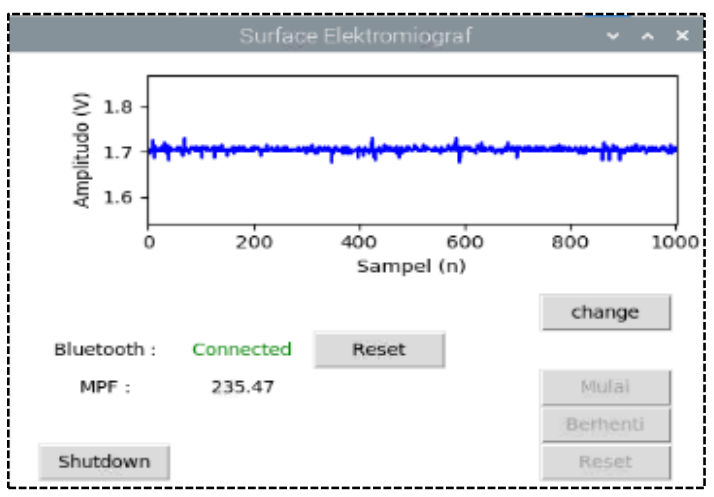

(a)

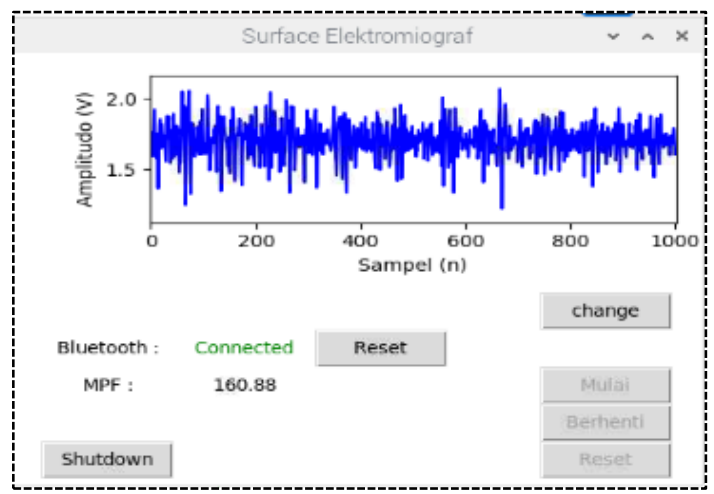

(b)

Gambar 11. (a) Pengujian 1 dengan kondisi ekstensi. (b). Pengujian 2 dengan kondisi fleksi.

Berdasarkan hasil pengujian yang dilakukan nilai MPF dari tiap pengujian mempunyai perbedaan, sehingga untuk menentukan jenis gerakan berdasarkan nilai MPF diperlukan range kemungkinan yang banyak terjadi, pada perangkat ini ketika gerakan tangan dalam kondisi fleksi maka range MPF yang diberikan kurang dari 180 karena pada beberapa pengujian yang sudah dilakukan nilai MPF ketika kondisi fleksi tidak melebihi 180 dan ketika kondisi ekstensi maka range MPF yang diberikan lebih dari 180 karena ketika kondisi ekstensi tidak kurang dari 180 akan tetapi mendekati nilai 180. Sehingga pemilihan range kurang dari 180 untuk kondisi fleksi dan lebih dari 180 untuk kondisi ekstensi bertujuan untuk memperkecil error yang dihasilkan setiap jenis gerakan. 


\section{KESIMPULAN}

Berdasarkan hasil penelitian yang telah dilakukan, maka dapat disimpulkan bahwa saat menggerakkan lengan secara fleksi dan ekstensi, rangkaian differential amplifier dan penguat inverting sebesar 1620 kali berfungsi dengan baik dalam menghasilkan sinyal otot dengan tegangan yang diinginkan. Sedangkan pengujian Vpp pada rangkaian low pass filter dan high pass filter dengan perhitungan secara teori mempunyai perbedaan yang linier, hal ini dikarenakan nilai komponen yang mempunyai toleransi sehingga menyebabkan adanya eror pada respon Vpp tiap frekuensinya. Pada rangkaian Notch Filter mampu meredam frekuensi dengan titik terendah berada pada frekuensi $40 \mathrm{~Hz}$. Penggunaan rangkaian adder untuk menggeser sinyal yang didapatkan dari rangkaian filter mempunyai persentase error sebesar 2.09\%. Deteksi jenis gerakan lengan dapat ditampilkan pada Layar LCD TFT dengan baik, namun penggunaan animasi dari sinyal pada tampilan LCD dapat mempengaruhi proses pengambilan data oleh ADC, sehingga data yang diambil tiap detik berbeda beda. Dari hasil ujicoba diketahui bahwa gerakan fleksi memiliki nilai MPF kurang dari $180 \mathrm{~Hz}$ dan gerakan Ekstensi memiliki nilai MPF lebih dari 180Hz.

\section{DAFTAR PUSTAKA}

[1] Maulana, R., Putri, R.R.M., 2018. Pengkondisian Sinyal Electromyography sebagai Identifikasi Jenis Gerakan Lengan Manusia. J. Teknol. Inf. Dan Ilmu Komput. 5, 297.

[2] Reaz, M. B. I., Hussain, M. S., \& Mohd-Yasin, F. (2006). Techniques of EMG signal analysis: detection, processing, classification and applications. Biological Procedures Online, 8(1), $11-$ 35. doi:10.1251/bpo115

[3] S. Higashi, D. Goto, S. Okada, N. Shiozawa and M. Makikawa, "Development of wearable EMG measurement system on forearm for wrist gestures discrimination," 2019 IEEE 1st Global Conference on Life Sciences and Technologies (LifeTech), 2019, pp. 250-251, doi: 10.1109/LifeTech.2019.8884009.

[4] A. elhakim, S. B. Setyawan, D. A. Santika, 2019. Detection of Muscle Strength Scale with Surface Electromyography using Multiple Channels Points Measurement Method, The 2nd International Conference on Vocational Innovation and Applied Sciences, ICVIAS22019048.

[5] Roberto Merletti; Dario Farina, "Surface EMG Decomposition," in Surface Electromyography: Physiology, Engineering, and Applications, IEEE, 2016, pp.180-209, doi: 10.1002/9781119082934.ch07.

[6] Y. Ning, X. Zhu, S. Zhu and Y. Zhang, "Surface EMG Decomposition Based on K-means Clustering and Convolution Kernel Compensation," in IEEE Journal of Biomedical and Health Informatics, vol. 19, no. 2, pp. 471-477, March 2015, doi: 10.1109/JBHI.2014.2328497.

[7] Zhilenkov, A.A., Kuznetsova, N.I., Zernov, O.I., 2018. Problem of automatic recognition of physical activity from surface electromyography signals, in: 2018 IEEE Conference of Russian Young Researchers in Electrical and Electronic Engineering (EIConRus). Presented at the 2018 IEEE Conference of Russian Young Researchers in Electrical and Electronic Engineering (EIConRus), IEEE, Moscow, pp. 1028-1031.

[8] R. Istenič, F. Negro, A. Holobar, D. Zazula and D. Farina, "Surface EMG pre-processing techniques for the detection of common input to motor neuron populations," 2013 6th International Conference on Biomedical Engineering and Informatics, 2013, pp. 256-259, doi: 10.1109/BMEI.2013.6746944.

[9] R. Multajam, M. Sanjaya, A. Sambas, N. Subkhi, and I. Muttaqien, "Desain Dan Analisis Electromyography (Emg) Serta Aplikasinya Dalam Mendeteksi Sinyal Otot," Alhazen J. Phys., vol. 2, no. 2, Art. No. 2, 2015.

[10] S. Setiowati, "Denoising Sinyal Electrocardiogram (Ecg) Menggunakan Metode Fast Fourier Transform Pada Sistem Deteksi Kantuk," J. Elektro Dan Telekomun. Terap, vol. 7, no. 1, pp. 789-796, Dec. 2020, doi: 10.25124/jett.v7i1.3309. 